\title{
EDITORIAL: HOW DO WE KNOW WHAT WE KNOW?
}

\author{
Christopher Fox
}

This is the second of two themed issues of TEMPO. TEMPO 291 was devoted to the consideration of a particular class of musical materials, string multiphonics: what they are, how they are produced and how they can be creatively deployed. The current issue focuses our attention on issues of diversity and, more specifically, how a recognition of the significance of gender can change the ways in which music is made, discussed and promoted.

Themed issues are relatively rare in TEMPO's history. In part this is because they cut across the grain of the journal's production pattern in which individual articles are proposed and submitted, coming together in the journal's habitually eclectic mix. Only occasionally does someone propose a collection of articles around a single subject: TEMPO 291 was Ellen Fallowfield's initiative; TEMPO 292 owes its existence to Louise Devenish.

But themed issues are also unusual because of an editorial assumption that our readers want to be presented with a range of different topics and perhaps this assumption needs to be challenged rather more often. Themed issues are interesting because the very narrowness of their focus throws into relief the enormity of the musical world: if there is so much to know about just one subject how much do we not know about the music we think we know? Even more significantly, both these issues of TEMPO demonstrate, to this reader at least, that there are areas of musical investigation about which I am so ignorant that (to paraphrase Donald Rumsfeld) I don't even know that they are there to be known.

Musical cultures are formed by tacit and solipsistic assumptions: we don't play this music because it doesn't exist; we know it doesn't exist because we don't play it. Yet the articles in this issue that discuss the expansion of the musical canon demonstrate that unknown music may, after all, actually turn out to exist once we have decided that its existence is important. Thirty years ago most of the classical music by women that featured in concert programmes was written by living composers; today there is a steadily growing repertoire of music by women that reaches back to the Renaissance.

In April 2019 the Dutch musicologist Kees Vlaardigerbroek wrote an article in De Volkskrant in which he argued that the 'enforced' introduction of music by women composers into concert programmes will push out 'Bach, Beethoven and Brahms' and may even endanger the very survival of classical music. ${ }^{1}$ Vlaardigerbroek's argument is, it seems to me, a form of intellectual protectionism and, like all protectionism, is an atavistic reaction to a dynamically changing world. It's

\footnotetext{
1 Kees Vlaardigerbroek, 'Bach was geen vrouw en westers. Nou en?’ De Volkskrant, 23 April 2019. www.volkskrant.nl/columns-opinie/bach-was-geen-vrouw-en-westers-nou-en $\sim \mathrm{b} 862 \mathrm{f} 3 \mathrm{fd} /$ ? referer $=$ https $\% 3 \mathrm{~A} \% 2 \mathrm{~F} \% 2 \mathrm{Fwww}$.google.com $\% 2 \mathrm{~F}$ (accessed 17 December 2019).
} 
understandable but it is also the enemy of cultural development. Instead of protectionism, I think the model of musical engagement that I am learning from these themed issues of TEMPO is one of vulnerability. We live in an era in which social media increasingly cocoons us in safe spaces; we don't even need to consciously devise them because the tech-giants' algorithms do it for us. When I want to be alarmed at my musical taste a quick glance at the side-bar on YouTube is usually enough.

How then do we break out of our musical echo chambers? What sort of strategies might make it possible to discover the music we don't know that we don't know? Recently I have found that something as simple as thinking about the map of the world is useful: so many nationalities, so many cultures, and yet most of the music that is programmed in Europe and north America originates in those continents. So, Strategy \#1: think of a country and then try to find some music from there.

In part the inspiration for this journey of discovery has come from the conductor and improviser, Ilan Volkov, with whom conversations often begin with a question about whether one has heard anything new. An example: through Ilan I have been introduced to the work of the Uruguayan composer Coriún Aharonián (1940-2017), ${ }^{2}$ pungent, visceral music that has also served as a sharp reminder that during my time as editor of TEMPO the music of South America has gone almost completely unrepresented. In TEMPO 284 we published an article on new music in São Paolo ${ }^{3}$ but I am acutely aware that one article, on the music of one group in one city, is not a proper response to the music of an entire continent.

At one level this editorial is an invitation to potential contributors to be ambitious, to take the journal into new territory, but it's also an invitation, perhaps only to me, to take more risks. Perhaps a more vulnerable approach to listening needs to go beyond geographical coverage, beyond scores and recordings, beyond concerts and installations, beyond the market-place of new music networks. Where this might lead I certainly don't know, but it sounds exciting.

\footnotetext{
${ }^{2}$ See, for example, Aharonián's Una carta (2001) www.youtube.com/watch?v=U_5kRzWIx9A (accessed 3 January 2020).

3 Christopher Dromey, 'New Horizons in Brazilian Contemporary Music: Grupo Novo Horizonte de São Paulo, 1988-99', TEMPO 284 (2018), pp. 52-67.
} 